\title{
The Little Rodeo That Never Was John Solensten
}

AUGUST NIGHTS IN OUR LITTLE TOWN in southern Minnesota were always hot and tense and a little short of breath. Maybe it was all the ripening going on-the terrible urging of the harvest. The fields had to be cut at just the right hours of ripeness; and, if farmers waited too long, a windstorm might come howling out of the northwest and wet and tangle the oats and barley into rotting unharvestable mats. Lots of worrying in August. Lots of kneeling to touch the delicate, nimble-whiskered heads of the oats and barley. Lots of pressing them between the hands before someone said, "Hitch up the binder. We got to cut it as soon as the dew is off." At the edge of town, the tall field corn leaned over, panting for space, into sun-scorched lawns and mingled here and there sinfully with hollyhocks and lilacs and raspberry bushes.

On main street it was popcorn. Art Baker's calliope popcorn wagon sat at the curb in front of the Farmer's State Bank and jiggled while Art made sputtering mounds of the stuff. The wagon was a rubber-tired, red, white and blue thing Art got from a bankrupt circus in Iowa. It had gilded gold gargoyles carved on its sides and its big, shiny brass pipes were bigger than any church organ pipes in town. The trouble was it could only play one tune, "The Skater's Waltz." It would be a hot, humid ninety-eight degrees and the calliope would play "The Skater's Waltz"-_oom, pa, pa; oom, pa, pa, oom"-again and again. Sometimes somebody would wait for an intermission, lean against the wagonmopping his forehead-and say to Art, "This ain't no skating rink out here, for God's sake!" But Art would never get mad. He would lean over slowly and say, "You never heard of roller skates, I suppose!' Then he'd hand over a butter-blotched, foot-high sack of popcorn and smile hugely. You could count on Art Baker, everybody said. It was a terribly serious town. Everybody expected that you could be counted on as soon as you could walk.

That night in August, 1938, was what people in that town called an "expectation night." It was a night between the heaves of weather and events. Things just had to change. The weather had been the same for a week, and the free movie-flickering on the green, brick wall of the John Deere implement store-it was the same old Gene Autry flashing those white teeth and singing the same old song, as the long head of his 
horse, Champion, hung over his shoulder and showed its big white teeth too.

I was sitting uptown on a bench under the real estate sign in the window of my father's office. It was during the last years of the Depression, and a lot of men were still working on WPA projects in town-gutters, curbs, sidewalks, bird fountains and toilets in the park. Many of those men were tired of hearing their wives say things like, "But it's good, honest work..." every night so they walked uptown about seven-especially nights when there was a bean-and-coffee feed and Arnie Flaten played the accordian and Joseph Murphy sold bootleg whiskey from out of the door panels of his 1934 Ford. Usually the men sulked about waiting for something to happen. Any little thing would do-a dog-fight, a falling star-anything.

I was sitting there with "Looney Larson," who never missed a cartoon at the theatre or on the wall of the John Deere store and who loved to do Porky Pig's, "Th- th- that's all folks!" a million times a day. We were watching for cars. We knew every Plymouth and Model A or B and De Soto and Chevrolet in the county. Knew every one. So when this big Hudson-Terraplane eased up to the curb down at the end of the street and sat there clatting its tappets and jiggling on its shocks like a kid who has to go to the toilet, we knew there were strangers in town.

"There's strangers in town, folks," Looney said to me.

There were strangers in town. Up and out of the back of the car, where she had been putting on her costume, pranced this lady with big legs and yellow stockings and red shoes. "She's into them stockings like sausage skins," Looney said. Everybody else saw her then. "She looks like Mae West," somebody said. "No, it's Fae West!" somebody else said. "Can't you read?"

Her hair looked electrified wiry and was the same farm-implement yellow as her stockings. She was carrying a little red-lettered sign pushed up hard under her bosom. It read:

\author{
PRE-VIEW \\ THE LITTLE RODIO TROOP \\ STARRING \\ FAE WEST THE GOLDEN GIRL \\ TEXAS GUNN \\ BRAMAS, ECT. \\ 8:00
}


"You see the shape of that sign?" someone asked. "Shape of what?" someone else asked. The lady didn't really walk. She cranked her legs along at the hips so the sign kept swinging back and forth back and forth. People stared hard.

Suddenly I realized that my father was standing next to me and staring too. He was wearing his gray suit as usual, (He never worked for the WPA) and his eyes were bright and sharp and funny inside themselves under his glasses and gray hair. His hair was tangled a little like it was wet or something. And his breath had that medicine smell again-like Listerine or something. It was a long time before I knew what that something was.

When this lady stopped right by him, he smiled a funny smile-thin and rubbery-almost a kid's silly smile.

It seemed kind of quiet then. Even Art Baker, the popcorn man, had stepped out of his wagon and stood out there watching to see what might happen.

"Hu-low, sir," the lady said.

Her eyebrows arched up squiggly and blue when she said it. The skin over her eyeballs was purple and spooky.

"You connected with the Buffalo Bill troupe?" my father asked in a hoarse voice. That made no sense unless you knew he was always talking about the time when he saw Cody's Wild West Show somewhere out in the mountains. He told me once that he wished he could've run off with that show and had some fun while he was young. I wasn't sure whether he was kidding or not though. His face looked serious when he asked it.

But she just said, "Sure am!" and kept pushing that sign up and up and up against her bosom.

"How could that be? That was a long time ago," my father said, frowning a little. His hair hung over his face so far he blew at it once in awhile to keep it off his mouth. 
"Yellow Hair, as they called him, was my relative-lovely blond man," she said, twitching around behind that sign.

"Really? A relative, you say?" He blew out of the side of his mouth, to push the hair away. Didn't do much good.

"Sure was. And now I should tell you we're on our way to bein' center attraction at the South Dakota State Fairgrounds, but it don't start for a week and it's a long way to Vermillion, S.D.."

"Oh?” my father said. “... The cap-i-tal?" He was stiff and shy with his words. He backed away a little and looked around at everybody with his eyes down. Some of them looked away or talked behind their hands.

"We need gasoline and meal money for our troupe-and hay and oats, of course. The whole she-bang is comin' along behind us. We can do a little rodeo for you for just fifty dollars-, tonight only-rope tricks and all," she said. She was puckering her mouth to make a big lipsticky "O" when she said "Only."

"A little rodeo?" my father asked, pursing his own mouth and going "Pfoo! Pfoo!" with his mouth to blow the hair away. "A little rodeo," he said again. I thought he was a little deaf sometimes.

"A wonderful once-in-a-lifetime little rodeo," she said. "Two big acts peaked with excitement!"

Now my father was the mayor of the town then and the unofficial social chairman of an unofficial town. The free suppers were his idea and the accordian and the Wilfahrt Sisters up on the stage singing "Little Old Lady Passing By" and "Alice Blue Gown." These attractions were supposed to bring more people spending more money into town, but there wasn't much to bring in.

Then my father's face looked long, serious and worried. "I wonder if any of the other council members are around tonight. I would have to clear anything with them, of course," he said, looking up and down the street for other council members. No luck.

"Of co-urse!" she said, arching her eyebrows again.

But he was still cautious. He scowled a little at Fae West. "Could we have a preview?" he asked. "Sure," she said, turning around and waving her hand back toward the Hudson-Terraplane. From where I stood, the front of that car looked like the cowcatcher on the front of a little locomotive. It looked like it was going to scoop up everything that ever got in front of it.

"How'm I going to get fifty dollars at 7:30?" my father asked, looking down at me and pushing at his hair. I just stared back at him. Fifty 
dollars was a sum remote as fifty stars to me then. But I guess my father had some cash from a down payment or something because he disappeared into his office and came back with the money in just a second. I don't know exactly why he took the risk. Nobody was urging him on or anything. Most of those men who worked on the WPA just stood there and smiled sadly at him or smiled easy thin smiles at Fae West. Maybe it was their sadness that made him do it, I don't know. They were a sad-eyed bunch-all of them.

At any rate, Father stood there with the money in the palm of his hand. He had a funny, tight, forced smile on his face and I wondered what he was waiting for. "Pfoo! Pfoo!" he went, blowing at his hair. Then, suddenly, Fae West grabbed the bills off his hand and poked them down in her bosom with a rich little throaty laugh. I saw my father's face turn gray and terrible like when I backed his De Soto across the street and into the grocery-store window. It was his "the world has run away, alas!" look.

Then, when Fae West went swinging her hips back toward the car, we heard a drawling voice announce, "Evenin', ladies and gents. I'm Texas Gunn." And there he was on the street in front of us. He seemed to step out of nowhere. I guess everybody was watching Fae and hadn't paid attention to anyone else. He was wearing flapping leather chaps and chewing an enormous wad of something and had a red kerchief around his neck. He had a big yellow nose and little eyes that worked up and down in narrow up-and-down slots in his pale white face.

He flicked that yellow rope in great, widening circles that got wider and wider. And he made the circle lie out horizontally and then up vertically. "Life has ups and downs," he kept saying, "life has its ups and downs."

Then somebody yelled out, "Where's the rest of the rodeo?"

Texas Gunn swung around toward that voice and seemed to sight at the person through the rope, coiling it out toward the crowd and making it whipple and zip. "You ever try to get a stompin' herd of mavericks and Brahma bulls into town in the back of a Hudson-Terraplane with an electric shift?" Gunn asked, chewing enormously. "They's a truck comin'. Hold you horses, amigo!"

"You ever had that rope pushed up your ..." somebody began. But they stopped in mid-sentence. Fae West had taken off her sign and had put a little fringe thing around her waist. She danced right into the rope between us and Gunn, smiling and doing a tap dance. Looney cried out, 
"That must be Shirley Dimple!" but Fae only smiled and danced with the rope going "Whick, whick, whick" around her. Then, while the rope did an easy, undulating circle around her, she sang, "Oh, That Strawberry Roan," puckering up her lipstick mouth on the "oh" and smiling lusciously. "Some strawberry!" somebody yelled. When he heard it, Texas Gunn whirled that rope over toward the crowd again like a whip.

Then all at once my father stood out there right in front of the whirling rope, his face gray and drawn so the skin was all full of deep lines. He raised his hands like he might catch the rope and stop the whirling. He didn't say a word, not a word. I was afraid the rope would whip his face, but he didn't seem to care. It looked like he wanted that rope to hit him. The sweat trickled down one cheek and he stepped one or two steps forward as stiff as a wind-up or something. I didn't know what to think. He looked even a little crazy with his hair that way and his eyes sunk in behind the glasses. "Pfoo! Pfoo!" he went, blowing at his hair.

That Gunn kept whirling a hole in the crowd and before we knew it, he was standing by the car on the driver's side. Fae West stepped up on the front bumper and wiggled by the headlights for just a second while my father shuffled toward them like he had on a pair of new shoes tied together right out of a store.

Then both of them stood-bowing toward us-each with one foot up on the car running boards and the doors open. Gunn was sweating and opened the collar of the white shirt he was wearing under the cowboy vest. He looked a quick white-eyed look of hate at my father. He stood only about ten feet away from the front of the car. "We'll be back in an hour with the whole she-bang!" Texas Gunn yelled, making a long sweeping bow to us and tossing that rope into the back seat.

Nobody cheered. In fact, they all looked a little mad. And then they all looked back and forth from my father to the car and back again. My father was too mad to talk. When he was really mad he couldn't say anything. But before anyone could say much, except, "Well, for God's sake, they better ..." that Hudson-Terraplane started up, backed away, clanked into gear and roared out into the August night. The street lights had come on, but it seemed awfully dark and quiet then. Not even any calliope music.

My father stood out there in the middle of the pavement-stark still, not moving a muscle. He looked like he might fly apart or rip himself 
apart from the inside out until someone yelled out, "Take it easy, Martin. It's only a joke." He didn't look at them or smile. He climbed slowly up on the little platform the accordian player and the Wilfahrt Sisters used in their show and announced in a dead voice that the free bean-supper was ready. They served the beans on paper plates with wooden spoons and coffee. I was scared. My father looked like a man at a hanging standing up there, and that platform looked like the ones they hanged people on in western movies. Then, when I looked up again, he was gone-disappeared like a ghost.

I found him a while later in his office sitting in the dark. The place smelled like medicine. His head seemed to be too loose on his shoulders. He didn't talk at all, just sat in his chair. He had two places in his life: his office and his study at home. He studied Greek at a Lutheran seminary in Milwaukee but the West called him to the business of land trading. He got as far as Sleepy Eye, Minnesota, where he met and married my mother. She was a schoolteacher. She said he was a bookish and confused man and should've been something else. I never knew what the something else was-even later.

He pulled out the big, gold Hamilton watch he kept on a leather fob under his belt. There was no way he could read it in the dark, but he looked at that round white face and said, "They're not ever coming." Then he paused and took a deep, sad breath. "The Greeks," he said, "having done what they could, suffered what they must." I left him alone with all that. He was strange and I was ten. I had to find Looney.

Outside in the street, the people sat quietly on curbs or fenders or benches digesting the bean-supper. Arnie Flaten was playing his mournful version of "Nicolina" on the accordian. Nobody was dancing or even talking much, just eating or whispering.

I found Looney standing on a yellow curb in the middle of the crowd. "I can't take this!" he yelled at me. He stomped his big foot on mine and punched me on the shoulder. "They tore out of here in their Terraplane, didn't they?" he yelled. "I guess so," I said, hunching down. "There ain't no rodeo, is there?" he yelled, punching again. "No," I said, hitting him back on the shoulder and looking at the people looking at us.

I wish I hadn't said no. Looney stood up and began doing his, "Thth- that's all, folks!" Looney Tunes routine. People began to laugh and then laugh until they bawled. "You got it right, Looney!" they yelled. "You got it right! There ain't no such thing as a free lunch!" 
I couldn't take it either then. I ran for home. On the way down the street I could hear "The Skater's Waltz"-oom, pa, pa; oom, pa, pa, oom. $\mathrm{Me}$, I wanted to skate right out of town.

I was awake when my father came home about midnight. He fell down on the lawn and inside the screen porch. I couldn't see him out of the window next to my bed, but I could see his black shoe out on the lawn by the driveway. It was like he had come apart. The shoe was sitting up like he had stepped right out of it. He had a lot of trouble with the inside door and the stairs. My mother's voice was strong and angry at first, then softened down to bed-talk with him. "How'm gonna pay it?" he cried again and again. My heart went out to him too, but I stayed in my bed thinking of that Hudson-Terraplane and the little rodeo that never came to town. Far off, on the vague edge of new sleep, I could hear faint, undulating calliope music as from a distant carnival. It was hot, but I pushed my head deep under my pillow and entered many tangled dreams. 